\title{
POSTIMPLANTATION DEVELOPMENT OF CLONED RABBIT EMBRYOS RECONSTRUCTED WITH FOETAL AND ADULT SKIN-DERIVED FIBROBLAST CELL NUCLEI*
}

\author{
Yuriy Kosenyuk, Maria Skrzyszowska, Barbara Gajda, \\ Bożenna Ryńska \\ Department of Biotechnology of Animal Reproduction, \\ National Research Institute of Animal Production, 32-083 Balice n. Kraków, Poland \\ Corresponding author: kosenyuk@izoo.krakow.pl
}

\begin{abstract}
The aim of the study was to determine the postimplantation developmental potential of nuclear transfer (NT) derived rabbit embryos, which were reconstructed with foetal fibroblast (FF) or adult skin fibroblast (AF) cell nuclei. A total of 97 embryos reconstructed with FF cell nuclei (Group I) were transferred into the oviducts of 6 pseudopregnant recipients and 101 embryos reconstructed with AF cell nuclei (Group II) were transferred to 6 foster mothers. The presence of fetuses (with the symptoms of early resorption of amniotic sacs) was confirmed in the $4 / 6(66.7 \%)$ and 1/6 (16.7\%) recipient-females in Group I and Group II, respectively. The implantation rate was significantly higher for cloned embryos originating from the oocytes receiving foetal fibroblasts than for those derived from adult skin fibroblasts $(P<0.1)$. Nonetheless, all pregnancies were lost and no progeny were obtained.
\end{abstract}

Key words: rabbit, somatic cell nuclear transfer, foetal fibroblast, adult skin fibroblast

The efficiency of somatic cell cloning in mammals is still low. In the case of cloned rabbit embryos, their development to term is extremely low. First viable somatic cell nuclear transfer-derived (SCNT) offspring have been obtained from embryos reconstructed with nuclei of fresh collected cumulus cells (Chesné et al., 2002). One year later NT-descended rabbit was obtained after reconstruction with fresh follicular cells (Challah-Jacques et al., 2003). The cloned rabbits were also generated from adult dermal fibroblasts (Li et al., 2006). However, among the 14 clones, most of the offspring died soon after birth; only three of the pups survived to adulthood. Li et al. (2009 a) showed that foetal fibroblast cell nuclei can support full-term embryo development following transfer to enucleated oocytes. In this ex-

*This study was financed from statutory activity, project no. 3341.1. 
periment, three newborn rabbits were obtained, one of which survived for more than 4 months. Cloned rabbits have been also produced from genetically modified adult fibroblast nuclei (Li et al., 2009 b) and mesenchymal stem cell nuclei (Zakhartchenko et al., 2011). The transgenic NT-descended rabbit was also generated using the chimeric somatic cell cloning technique. In this case, karyoplast of transgenic adult skin fibroblast was microsurgically transferred into one, previously enucleated, blastomere of 2-cell non-transgenic embryos, while the second one remained intact (Skrzyszowska et al., 2006). In turn, Meng et al. (2009) investigated the effect of trichostatin A (TSA) treatment on the development of the SCNT rabbit embryos reconstructed with cumulus cell nuclei. Both the TSA-treated and the untreated embryos can develop to term, but none of the offspring from TSA-treated embryos survived to adulthood. However, Xu et al. (2007) showed that TSA affects the enhancement of NT-embryo quality. Shi et al. (2008) indicate that the histone acetylation pattern of TSA-treated SCNT embryos appeared to be more similar to the model of normal embryos. They suggest that TSA could improve nuclear reprogramming after nuclear transfer. Proper distribution patterns of histone acetylation, which characterize specific chromatin modifications, play a key role in nuclear reprogramming after their transfer. Epigenetic reprogramming, which occurs in preimplantation embryos, is apparently species-specific and depends on donor cell type (Dean et al., 2003; Hiendleder et al., 2004; Santos et al., 2003). Little is known about epigenetic reprogramming in rabbits. The absence of demethylation during early development correlated with low rabbit cloning efficiency. In contrast with mouse, rat, pig and cattle, rabbit embryos exhibited equally high methylation levels of the paternal and maternal genomes from the zygote to the 16-cell stage (Shi et al., 2004). The histone acetylation status of rabbit somatic cells, which may also contribute to a low cloning efficiency in this species, has not been studied so far.

Our study was designed to determine the postimplantation developmental potential of rabbit cloned embryos reconstructed with foetal and adult skin fibroblast cell nuclei.

\section{Material and methods}

\section{Establishment of rabbit fibroblast cell lines}

Rabbit foetal fibroblasts were established from 15-16-day-old foetuses removed from rabbit uteri by caesarean section. Foetal and adult skin tissue samples were cut into small pieces using a tissue chopper $(0.5 \mathrm{~mm})$ and tissue explants were placed in a culture flask with a small volume of Dulbecco Modified Eagle Medium (DMEM, Gibco Invitrogen Co., UK), enough to wet the bottom of flask but not too much to cause the tissue pieces to float. For the first 2 to 3 days of incubation, a few more drops of the medium were added every 2 to 3 hours, then gradually more medium was added when pieces had definitely attached. Cultures were replenished 2 to 3 times per week. For the primary cultures of dermal fibroblasts, modified Dulbecco Minimum Essential Medium, which had been supplemented with $10 \%$ foetal bo- 
vine serum (FBS, Sigma, St Louis, MO), 2 mM non-essential amino acids (NEAA, Sigma), $2 \mathrm{mM}$ L-glutamine (Sigma), $0.36 \mathrm{mM}$ sodium pyruvate (Sigma), and 1\% antibiotic-antimycotic solution (Sigma), was used. After removal of the explants (days 5 to 6), monolayers of fibroblast cells were harvested using DMEM supplemented with $0.25 \%$ trypsin-EDTA (Sigma). Cells were subsequently cultured up to a total confluency and then passaged at least three times. Cells harvested from flasks by trypsinization were washed in $10 \mathrm{~mL}$ HEPES-buffered Tissue Culture Medium 199 (TCM 199-HEPES, Sigma) with 10\% FBS and centrifuged at $200 \times \mathrm{g}$ for 10 min. The cell pellet was then suspended in FBS containing 9\% dimethyl sulfoxide (DMSO, Sigma) before freezing in a Minicool freezer.

Cryopreserved donor cells were thawed at $37^{\circ} \mathrm{C}$ and $200 \mu \mathrm{L}$ of FBS was added. The suspension was kept at room temperature for $10 \mathrm{~min}$, then $800 \mu \mathrm{L}$ of cell culture medium was added and the cells were centrifuged at $300 \times \mathrm{g}$ for $5 \mathrm{~min}$. The supernatant was removed and $50 \mu \mathrm{L}$ of manipulation medium was added. Frozen/thawed adult skin fibroblast cells, which had been cultured in vitro up to a total confluency state to synchronize their mitotic cycle at G0/G1 through contact inhibition of migration and proliferative growth, were used in the somatic cloning procedure.

\section{Oocyte collection of in vivo matured oocytes - the source of recipient cells}

In vivo matured oocytes were recovered from superovulated donor females. New Zealand female rabbits were injected intramuscularly with 100 IU of PMSG (Serogonadotropin, Biowet) and intravenously with $100 \mathrm{IU}$ of hCG (Biogonadyl, Biomed) $72 \mathrm{~h}$ later to induce superovulation. Ovulated oocytes were recovered from the oviducts $17-18 \mathrm{~h}$ after hCG injection by flushing with Dulbecco's PBS (DPBS) solution supplemented with $1 \mathrm{mg} / \mathrm{ml}$ BSA. Oocyte-cumulus cell complexes (OCCs) were incubated in medium containing $1 \mathrm{mg} / \mathrm{ml}$ hyaluronidase for 1 to $2 \mathrm{~min}$. Cumulus cells were removed by gentle pipetting with a small-bore pipette. Metaphase II oocytes with distinctly expelled first polar body and with evenly granulated cytoplasm were selected as a source of recipient-oocytes for exogenous (somatic) cell nuclei.

\section{Preparation of NT-derived embryos}

Cumulus-denuded in vivo-matured oocytes were incubated in the medium supplemented with $0.4 \mu \mathrm{g} / \mathrm{mL}$ demecolcine for 40 to $50 \mathrm{~min}$. The treated oocytes were subsequently transferred into DPBS medium containing $4 \mathrm{mg} / \mathrm{mL} \mathrm{BSA}-\mathrm{V}$ and $5 \mathrm{mg} / \mathrm{mL}$ cytochalasin B. Metaphase chromosomes, which had been allocated into the chemically induced protrusion of the plasma membrane, were removed microsurgically. The chemically assisted enucleation was accomplished by aspirating the ooplasmic cone, which contained the condensed chromosome mass. The single nuclear donor cells were inserted into perivitelline space of enucleated oocytes (ooplasts). Foetal fibroblast-ooplast couplets (FF-OCs; Group I) or adult fibroblast-ooplast couplets (AF-OCs; Group II) were fused with three consecutive DC pulses of $3.2 \mathrm{kV} / \mathrm{cm}$ for $20 \mu \mathrm{sec}$, which were delivered with the use of a BTX Electrocell Manipulator 200 (BTX, San Diego, CA). The fusion medium consisted of $0.3 \mathrm{M}$ mannitol supplemented with $0.05 \mathrm{mM} \mathrm{CaCl}_{2}, 0.1 \mathrm{mM} \mathrm{MgSO}_{4}$ and $0.2 \mathrm{mg} / \mathrm{ml}$ fatty acid free BSA. After a $1 \mathrm{~h}$ delay, the reconstructed oocytes were chemically activated by exposure 
to $5 \mu \mathrm{M} / \mathrm{L}$ calcium ionomycin for $5 \mathrm{~min}$, followed by their incubation in B2 medium supplemented with mixture of $2 \mathrm{mM} / \mathrm{L}$ 6-dimethylaminopurine (6-DMAP) and $10 \mu \mathrm{g} / \mathrm{ml}$ cycloheximide (CHXM), for $1 \mathrm{~h}$.

\section{Embryo culture and transfer}

After activation, the reconstructed embryos were in vitro cultured in $\mathrm{B} 2$ medium for 24 to $26 \mathrm{~h}$ at $38.5^{\circ} \mathrm{C}$, in a humidified atmosphere of $5 \% \mathrm{CO}_{2}$ and $5 \% \mathrm{O}_{2}$ in air.

NT-derived embryos were transferred into recipient does, with the pseudopregnancy status $22 \mathrm{~h}$ delayed compared with oocyte donors (asynchronous recipients). Cloned embryos at 2- to 4-cell stages were surgically transferred through the infundibulum into oviduct of recipient-females. The pregnancy was determined by palpation or ultrasonographic diagnostics between days 14-17 after embryo transfer.

\section{Statistical analysis}

The cleavage rate of reconstructed embryos and the differences in pregnancy rates between two groups of recipients were compared with chi-square test.

\section{Results}

In Group I, a total of 157 ooplast-foetal fibroblast cell couplets were produced and $128(81.5 \%)$ of them were successfully fused. Out of 128 cultured NT embryos, 97 (75.8\%) were cleaved. All cleaved embryos were transferred into the oviducts of 6 pseudopregnant recipients (an average of 16 cloned embryos per recipient). Early postimplantation development was confirmed in the 4/6 (66.7\%) recipients. However, the diagnosed foetuses displayed the symptoms of early resorption of amniotic sacs.

In Group II, a total of 125 ooplast-adult skin fibroblast couplets were produced and $104(83.2 \%)$ of them were fused. Out of 104 cultured NT embryos, $101(97.1 \%)$ were cleaved. All cleaved embryos were transferred to 6 foster mothers (an average of 17 cloned embryos per recipient). Early postimplantation development was confirmed in the $1 / 6(16.7 \%)$ recipient (Table 1$)$.

Table 1. Postimplantation development of cloned rabbit embryos reconstructed with fetal and adult fibroblast nuclei

\begin{tabular}{l|c|c|c|c|c|c}
\hline $\begin{array}{c}\text { Nuclear } \\
\text { donor cells }\end{array}$ & $\begin{array}{c}\text { No. of ooplast- } \\
\text {-somatic cell } \\
\text { couples }\end{array}$ & $\begin{array}{c}\text { No. of fused } \\
\text { couples } \\
(\%)\end{array}$ & $\begin{array}{c}\text { No. of } \\
\text { cleaved } \\
\text { embryos (\%) }\end{array}$ & $\begin{array}{c}\text { No. of } \\
\text { transferred } \\
\text { embryos }\end{array}$ & $\begin{array}{c}\text { No. of recipient- } \\
\text {-females }\end{array}$ & $\begin{array}{c}\text { No. of pregnant/ } \\
\text { delivering } \\
\text { recipients (\%) }\end{array}$ \\
\hline $\begin{array}{l}\text { Foetal } \\
\text { fibroblasts }\end{array}$ & 157 & $\begin{array}{c}128 \\
(81.5)\end{array}$ & $\begin{array}{c}97 \mathrm{~A} \\
(75.8)\end{array}$ & 97 & 6 & $4(66.7) \mathrm{a} / 0$ \\
$\begin{array}{l}\text { Adult skin } \\
\text { fibroblasts }\end{array}$ & 125 & $\begin{array}{c}104 \\
(83.2)\end{array}$ & $\begin{array}{l}101 \mathrm{~B} \\
(97.1)\end{array}$ & 101 & 6 & $1(16.7) \mathrm{b} / 0$ \\
\hline
\end{tabular}

\footnotetext{
A, B $-\mathrm{P}<0.001$.
}

$\mathrm{a}, \mathrm{b}-\mathrm{P}<0.1$. 
The cleavage rate of cloned embryos reconstructed with AF was significantly higher than oocytes reconstructed with $\mathrm{FF}(76 \%$ vs. $97 \%, \mathrm{P}<0.001)$. In contrast to this result implantation rate was higher in the case of embryos which were reconstructed with foetal fibroblast nuclei than in those which were reconstructed with adult skin fibroblast cell nuclei $(\mathrm{P}<0.1)$. However, all pregnancies were lost and no progeny was obtained. Cloned rabbit embryos were characterized by high intrauterine implantation rates, but also by failure in development to term.

\section{Discussion}

We have examined the postimplantation developmental competencies of the rabbit embryos reconstructed with fibroblast cell nuclei originating from foetal or adult skin tissues.

The type of nuclear donor cells can be one of the important factors affecting the cloning efficiency. In our study, significant differences in the pregnancy rate between two experimental groups of recipient-females were found. The nuclei of foetal fibroblasts revealed high potential to bring the development of cloned embryos at least to the middle of gestation. The results of our study did not confirm those obtained by other authors (Li et al., 2009 a). They showed that potential of cloned embryos reconstructed with foetal fibroblast nuclei was lower than for those reconstructed with adult fibroblast nuclei (Li et al., 2006). Nonetheless, foetal fibroblasts can give rise to live adult rabbits (Li et al., 2009 a). According to Yang et al. (2007) the developmental competences to reach the blastocyst stage of SCNT rabbit embryos reconstructed with cumulus cell and foetal fibroblast nuclei were similar. However, after transfer into recipient-females, cumulus cell cloned embryos induced a higher pregnancy rate as compared to foetal fibroblast cloned embryos. However, almost all pregnancies with both types of cloned embryos were lost by the middle of gestation and only one, live cumulus cell-derived rabbit was obtained. It is very surprising that rabbit cloned embryos are marked by extremely poor postimplantation potential, despite their high ability to reach the blastocyst stage in vitro. On the other hand, Cervera and Garcia-Ximenez (2003) indicated that the ability of cumulus-descended embryos to reach morula and blastocyst stage was significantly higher than that of foetal fibroblast-descended embryos. But, Liu et al. (2004) reported a lower developmental potential of cumulus cell-derived embryos than for adult fibroblasts. Chesné et al. (2002) found that the timing of pre-implantation development of cloned rabbit embryos was delayed compared with normal embryos by about one day. Thus, the cloned embryos were transferred to $22 \mathrm{~h}$-delayed asynchronous recipients, which were mated to vasectomized males $22 \mathrm{~h}$ after the oocyte donor females. Joung et al. (2004) showed that the oviducts of asynchronous recipients produce more mucin coat around transferred embryos than synchronous ones. The authors indicated that asynchrony resulted in higher pregnancy and birth rates than synchrony. It was confirmed that an asynchronous scheme of embryo transfer is important especially in somatic cell cloning in rabbits. We have also transferred cloned embryos into recipient fe- 
males with $22 \mathrm{~h}$ asynchrony in comparison to the oocyte donor. After transfer into recipient, foetal cell cloned embryos induced significantly higher initial pregnancy rate as compared with adult cell cloned embryos. However, the postimplantation development of embryos reconstructed with either cell type was limited to the beginning or early phase of gestation. This result indicates that other, donor cell type-independent, factors may impair embryonic development in the second period of gestation. It seems that the number of cloned embryos, transferred into one recipient-female can play some role in occurrence of implantation frequency. We have transferred an average of 16 cloned embryos per recipient. Challanah-Jacques et al. (2003) found that increasing the number of reconstructed embryos transferred into one foster (up to 45 per recipient) did not increase the chances of full-term pregnancy. The authors transferred seven to $10 \mathrm{NT}$ embryos into each oviduct. In the rabbit contrary to the mouse, a litter of only one fetus can routinely be observed, which is favourable for full-term development of nuclear transfer derived fetuses (Challanah-Jacques et al., 2003). Adams (1960) estimated the amount and distribution of prenatal mortality in the rabbit. It was estimated that $7 \%$ of the in vivo fertilized embryos died shortly after implantation. From this population, $66 \%$ died between days 8 and 17, and $27 \%$ were lost between days 17 and 23 of gestation. Most of the foetal mortality in rabbits occurs between days 8 and 17 of gestation. This is the period in which the development of the placenta takes place, and it is considered as an especially critical moment for survival of the fetus. Rabbits develop two kinds of placentas: an inverted yolk sac placentation that appears at the beginning of gestation and a chorioallantoic placenta, which is the definitive placenta. The early embryo relies upon the yolk sac for its nutrition, but this structure begins to degenerate about day 10 of pregnancy, when the chorioallantoic placenta supersedes it. The development of chorioallantoic placenta begins at day 8 of gestation, but its characteristics are still not fully developed up to day 12. Thus, the time of embryo implantation may be critical for the later fate of transferred embryos, particularly NT-derived embryos.

The second factor which can affect the efficiency of cloning, is artificial activation of reconstructed oocytes. Chemical post activation with 6-DMAP and CHXM of reconstructed rabbit embryos may improve their reprogramming and subsequent development. Combined treatment with 6-DMAP and CHXM induces a decrease in intracellular concentration and activity of cyclin-depended kinases (CDKs), such as maturation promoting factor (MPF) and mitogen-activated protein kinases (MAPKs). Low levels of kinases are required for activation of oocytes and reconstructed embryos. Cycloheximide, the protein synthesis inhibitor, suppressed resynthesis of cyclin B and A and resulting transient inactivating CDKs. Treatment of oocytes with 6DMAP, the inhibitor of protein phosphorylation, can have a cooperative effect with CHXM, as shown by improved developmental capacity of reconstructed embryos.

During preimplantation development, Shi et al. (2004) observed a significantly higher rate of developmental failure in cloned rabbit embryos compared with in vivo-fertilized embryos. The reduction of viability in cloned embryos can also be associated with chromosomal aneuploidies. There was a good correlation between chromosomal aneuploidy frequency and the rate of developmental arrest during the preimplantation stage: $48 \%$ of in vivo-fertilized and $79 \%$ of rabbit SCNT embryos 
failed to develop to the blastocyst stage, respectively. The failure to segregate chromosomes properly and to maintain ploidy is one important cause of early embryo loss and chromosomal abnormalities may contribute significantly to the low overall success rate of mammalian embryo cloning.

The difficulties with rabbit cloning may at least partially be due to insufficient remodelling of somatic cell nuclei in oocytes. Cloning of rabbits from cultured donor cells provides the basis for further development of SCNT in this species, which would have a plethora of important applications in biomedicine and biotechnology.

\section{References}

A d a m s C.E. (1960). Prenatal mortality in the rabbit, Oryctolagus cuniculus. J. Reprod. Fertil., 1: $36-44$.

Cervera R.P., Garcia-Ximenez F. (2003). Oocyte age and nuclear donor cell type affect the technical efficiency of somatic cloning in rabbits. Zygote, 11 (2): 151-158.

Challah-Jacques M., Chesné P., Renard J.P. (2003). Production of cloned rabbits by somatic nuclear transfer. Cloning Stem Cells , 5(4): 295-299.

Chesné P., Adenot P.G., Viglietta C., Baratte M., Boulanger L., Renard J.P. (2002). Cloned rabbits produced by nuclear transfer from adult somatic cells. Nat. Biotechnol., 20 (4): 366-369.

Dean W., S a n tos F., Reik W. (2003). Epigenetic reprogramming in early mammalian development and following somatic nuclear transfer. Semin. Cell Dev. Biol., 14 (1): 93-100.

D innyés A., D a i Y., B a rber M., Li u L., X u J., Z hou P., Y ang X. (2001). Development of cloned embryos from adult rabbit fibroblasts: effect of activation treatment and donor cell preparation. Biol. Reprod., 64: 257-263.

Hi end l e d e r S., Mund C., R e i chen ba ch H.D., W en igerkind H., B re m G., Zakhart c he n k o V., L y k o F., W o 1 f E. (2004). Tissue-specific elevated genomic cytosine methylation levels are associated with an overgrowth phenotype of bovine fetuses derived by in vitro techniques. Biol. Reprod., 71 (1): 217-223.

Inoue F., Matsuda J., Ohkoshi K., Furusawa T., Takahashi S., Sasada H., S a to E., Tokunaga T. (2006). Differences in gene expression patterns between somatic cell nuclear transfer embryos constructed with either rabbit granulosa cells or their derivatives. Anim. Reprod. Sci., 93: 76-87.

J oung S.Y., Kim H.J., Choi W.S., I m K.S., Le e S.H., P a rk C.S., J in D. (2004). Effect of transferring in vitro-cultured rabbit embryos to recipient oviducts on mucin coat deposition, implantation and development. Zygote, 12: 215-219.

Li S., Ch en X., F ang Z., S hi J., S h en g H.Z. (2006). Rabbits generated from fibroblasts through nuclear transfer. Reproduction, 131: 1085-1090.

Li S., Chen X., Shi J., Gu o Y., Y in C., D u L., Sheng H.Z. (2009 a). Cloning rabbits from fetal fibroblasts. Livest. Sci., 122: 77-80.

Li S., Gu o Y., Sh i J., Y in C., Xing F., X u L., Zhang C., Li u T., L i Y., L i H., D u L., Chen X. (2009 b). Transgene expression of enhanced green fluorescent protein in cloned rabbits generated from in vitro-transfected adult fibroblasts. Transgenic Res., 18: 227-235.

Li u J.L., S ung L.Y., Du F., Julian M., Ji ang S., B arber M., Xu J., Tian X.C., Y ang X. (2004). Differential development of rabbit embryos derived from parthenogenesis and nuclear transfer. Mol. Reprod. Dev., 68 (1): 58-64.

Meng Q., Polgar Z., Li u J., D innyes A. (2009). Live birth of somatic cell-cloned rabbits following trichostatin A treatment and cotransfer of parthenogenetic embryos. Cloning Stem Cells., 11 (1): 203-208.

Mitali pov S.M., White K.L., Farrar V.R., Morrey J., Reed W.A. (1999). Development of nuclear transfer and parthenogenetic rabbit embryos activated with inositol 1,4,5-trisphosphate. Biol. Reprod., 60: 821-827. 
Santos F., Zakhartchenko V., Stojkovic M., Peters A., Jenuwein T., Wolf E., R e i k W., D e a n W. (2003). Epigenetic marking correlates with developmental potential in cloned bovine preimplantation embryos. Curr. Biol., 13: 1116-1121.

Shi W., Dirim F., Wolf E., Zakhartchenko V., Ha f T. (2004). Methylation reprogramming and chromosomal aneuploidy in in vivo fertilized and cloned rabbit preimplantation embryos. Biol. Reprod., 71: 340-347.

Skrzyszowska M., S morąg Z., Słomski R., Kątska-Książkiewicz L., Kalak R., Michalak E., Wielgus K., Lehmann J., Lipiński D., Szalata M., Pławski A., S a mi e c M., Jura J., Gajda B., Ryńska B., Pieńkowski M. (2006). Generation of transgenic rabbits by the novel technique of chimeric somatic cell cloning. Biol. Reprod., 74: 1114-1120.

S ti c e S.L., R o bl J.M. (1988). Nuclear reprogramming in nuclear transplant rabbit embryos. Biol. Reprod., 39 (3): 657-664.

Xu J., Sung L.-Y., Zhang J., Tian X., Chen Y.E., Yang X., Du F. (2007). Trichostatin A improved the quality of rabbit nuclear transfer embryos. Reprod. Fertil. Dev., 19 (1), p. 165.

Yang F., Hao R., Kess e r B., Brem G., W olf E., Zakhartchenko V. (2007). Rabbit somatic cell cloning: effect of donor cell type, histone acetylation status and chimeric embryo complementation. Reproduction, 133: 219-230.

Y in X.J., Tani T., Kato Y., T sunoda Y. (2000). Development of rabbit parthenogenetic oocytes and nuclear-transferred oocytes receiving cultured cumulus cells. Theriogenology, 54 (9): 1469-1476.

Zakhartchenko V., Flisikowska T., Li S., Richter T., Wieland H., Durkovic M., Rottmann O., Kess ler B., Gungor T., Brem G., Kind A., Wolf E., Schnieke A. (2011). Cell-mediated transgenesis in rabbits: chimeric and nuclear transfer animals. Biol. Reprod., 84: $229-237$.

Accepted for printing 10 XI 2011

\section{YURIY KOSENYUK, MARIA SKRZYSZOWSKA, BARBARA GAJDA, BOŻENNA RYŃSKA}

\section{Poimplantacyjny rozwój klonalnych zarodków królika zrekonstruowanych z jąder fibroblastów płodowych oraz fibroblastów tkanki skórnej dorosłych osobników}

\section{STRESZCZENIE}

Badania przeprowadzono w celu określenia poimplantacyjnych kompetencji rozwojowych zarodków klonalnych królika, w zależności od pochodzenia komórek fibroblastycznych - dawców jąder, po aktywacji chemicznej z użyciem jonomycyny oraz kombinacji 6-dimetyloaminopuryny (6-DMAP) i cykloheksimidem (CHXM). 97 zarodków klonalnych zrekonstruowanych z jąder fibroblastów płodowych było przeniesionych do jajowodów 6 samic-biorczyń (Grupa I). 101 zarodków klonalnych zrekonstruowanych z jąder fibroblastów tkanki skórnej dorosłych osobników było przeniesionych do jajowodów 6 samic-biorczyń (Grupa II). Badania ultrasonograficzne samic-biorczyń, przeprowadzone w 14. dniu po przeniesieniu zarodków, potwierdziły obecność pęcherzy płodowych z objawami wczesnej resorpcji u 5 z 12 królic. Spośród 5 ciężarnych biorczyń, 4 biorczynie otrzymały zarodki zrekonstruowane z jąder fibroblastów płodowych $(66,7 \%)$, a tylko jedna z biorczyń otrzymała zarodki zrekonstruowane $\mathrm{z}$ jąder fibroblastów tkanki skórnej dorosłych osobników (16,7\%). Mimo że we wszystkich przypadkach ciąża została zatrzymana w pierwszej połowie, to wyniki tych badań wyraźnie potwierdziły wyższe zdolności jąder komórkowych fibroblastów płodowych do pokierowania rozwojem zarodków klonalnych na etapie poimplantacyjnego rozwoju niż jąder fibroblastów skóry dorosłych osobników $(\mathrm{P}<0.1)$. 